\title{
THE INFLUENCE OF COMMUNICATION, SHARE VALUE, AND OPPORTUNISTIC BEHAVIOR CONTROL ON CUSTOMER LOYALTY IN INTERNET BANKING
}

\author{
${ }^{1}$ Dian Purnamasari, ${ }^{2}$ Nurul Aini, ${ }^{3}$ Joko Suyono \\ Narotama University, Indonesia

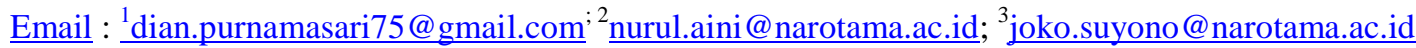

\begin{abstract}
Purpose: This paper aims to analyze the correspondency of multiple variables such as communication, share value, opportunistic behavior control, trust, and loyalty in the case of internet banking. The analysis is mediated by customer's trust.
\end{abstract}

Design/methodology/approach: The method used is statistic-descriptive, followed by purposive sampling as the data collection method. Design used is cross sectional.

Findings: Among the hypotheses proposed, there are 4 that show positive results. Those include share value that has positive impact on the customer's trust on Bank Jatim, internet banking customer's loyalty on Bank Jatim, and customer's loyalty in using the Bank's internet banking mediated through trust.

Research limitations/implications: The sample includes 135 respondents from Bank Jatim Surabaya that use internet banking.

Practical implications: Among the hypotheses proposed, 2 out of 6 are not acceptable because the statistics show inadequate percentage.

Paper type: This paper can be categorized as a case study.

Keyword: communication; internet banking; opportunistic behavior control; share value.

Received: August $19^{\text {th }}, 2020$

Revised: September $12^{\text {nd }}, 2020$

Published: September $30^{\text {th }}, 2020$

\section{I.INTRODUCTION}

Internet banking helps the customers in doing transactions, it also becomes the solution for infrastructure development with minimal funding (Nur \& Jaka Isgiyarta, 2015). However, the emergence of internet banking also poses the emergence of a new type of crime using the internet banking.

This crime threatens the security and privacy of both private data accounts and the finance inside the accounts; which affect the customers' willingness in using internet banking. The crime also influences in customers' distrust and fear in using internet banking. This fear could also cause the customers' reluctance in using internet banking in the future because there is small percent of guarantee on the data privacy (Istiarni \& Hadiprajitno, 2014).

The bank has to make sure its system enables for data privacy in order to earn trust from the customers. If the customers trust the bank's banking system, there is a possibility of loyalty increasing in the customer to use the bank's service. There are some influencing factors that could increase the customers' trust in using internet banking. The factors include shared value, communication, and oppostunistic behavior control (Sa'diyah \& Aziroh, 2014).

The banking ethics that should be considered seriously by the bank is structured by the government similar to a law, this law is to be followed by all the banks in the country in order to ensure the trust 
regarding security and privacy of the customers. Thus, the three factors becomes an indicator in measuring the shared value between the customer and the bank (Chen \& Dibb, 2010).

This article aims to analyze the influence of communication, shared value, and opportunistic behavior on the customers' trust and loyalty mediated by trust. The respondences are the customers of Bank Jatim Surabaya who had used or is currently using Bank Jatim's internet banking service.

\title{
A. Previous Study
}

There were previous studies that considered the three factors above such as (Amin, Isa, \& Fontaine, 2013), (Tumbel, 2017), (Taufan, Prakoso, \& Farida, 2018) and had proved positive results on the customers' trust and loyalty. There is also (wu, Weng, \& Huang, 2012) that analyzed the connection between variables such as the relation termination fee, teamwork advantage, shared value, oppostunistic behavior, communication, trust, and else. Wu proved that shared value and communication have positive influence on trust which also reacts positively on the loyalty of the customers. However, the opportunistic behavior does not, and this factor is considered to be evaluated in this article.

\author{
B. Hypotheses \\ $\mathrm{H}_{1}$ : Share value influences positively on Trust \\ $\mathrm{H}_{2}$ : Communication influences positively on Trust \\ $\mathrm{H}_{3}$ : Opportunistic Behavior Control influences positively on Trust \\ $\mathrm{H}_{4}$ : Share value influences positively on customer's e-banking Loyalty \\ $\mathrm{H}_{5}$ : Opportunistic Behavior Control influences positively on customer's \\ e-banking Loyalty \\ $\mathrm{H}_{6}$ : Trust influences positively on customer's e-banking Loyalty \\ $\mathrm{H}_{6 \mathrm{a}}$ : Share value influences positively on customer's e-banking loyalty \\ through Trust \\ $\mathrm{H}_{6 \mathrm{~b}}$ : Opportunistic Behavior Control influences positively on customer's \\ e-banking Loyalty through Trust
}

\section{II.METHODOLOGY}

\section{A. Research Design}

This is cross sectional which is a one-time only data collection from certain sample(s). This research is also a non-experimental research in which the variables analyzed are not manipulated in any shape or form because the manifestation ahd already occurred (Kerlinger \& Lee, 2000)

\section{B. Population and Sample}

The population for this research is Bank Jatim Surabaya and the samples are a number of customers in the said bank that use the bank's e-banking service. Purposive sampling is used on 135 respondents (5 x 27 indicators). The number of respondents are received using 5 times the indicator analyzed. There are also criterias embedded for the samples which include: (a) Respondent is a client and had used the internet banking service of Bank Jatim Surabaya, (b) Respondent is able to use the features of internet banking, (c) Respondent's age is at the minimum of 18 years old with the asumptions that the said age is considered as an adult and could decide its own choice, (d) Respondent is living in, or, staying at Surabaya.

Questionnaires are used as the collecting method. The questions considered are the ones that fulfills the criteria to measure the variables. Scale value shows the respondents' Agreement and Disagreement level towards the questions asked. The measurement scale of the five factors above reaches 5 scales that include: 1-Highly disagree, 2-Disagree, 3-More or less agree, 4-Agree, and 5-Highly agree.

\section{Research Variable X1 : Share Value}

The low value of security could influence the client's trust by significant percent. This percentage could also be influenced by ethics which refer to the bank's codes in giving information; the falsely given information and selling the information of other onto a third party are included in ethics. 
In the case of internet banking, the client will be communicating with machines instead of humans. The higher the social communication showed by a bank website, the higher it influences the trust of the customer and urges the customer to do online transaction.

\section{X3 : Oppostunistic Behavior Control}

The indicator in measuring this factor is regulatory control that shows the function of identification, measurement, inspection, and control the risks of internet banking operation to strengthen the security in doing transactions (Laroche, Habibi, \& Richard, 2013).

M : Trust

Refers to the willingness of an individual to act a certain activity based on the trust that the partner will give what s/he wishes for and a kind of hope that is generally gotten by someone Barnes (2013)

\section{Y : Loyalty}

Commitment to buy a certain product or become a regular customer of a certain service in the future although there is possibility of the change in behavior in the market world (Kotler \& K, 2016)

\section{Data Analysis Method}

The data collected could be categorized as quantitative, thus would be analyzed using statisticsdescriptive method based on the data. Aside from that, Partial Least Square will also be used in which will include (1) an outer model that will be evaluated using convergent validity and its indicators, composite reliability for block indicator; and, (2) inner model in which is evaluated by looking at the percentage of variance explained, which is by looking at the $R^{2}$ (R Square) to construct latent dependent and measuring the coefficiency of its structural track.

\section{Equations}

In structural model, the Stone-Geisser value (Q2) that is bigger than 0 (zero) indicates the predictive relevance of the model path to construct it.

$$
\mathrm{f} 2=\frac{R_{\text {included }}^{2}-R_{\text {excluded }}^{2}}{1-R_{\text {included }}^{2}} \quad \mathrm{q} 2=\frac{Q_{\text {included }}^{2}-Q_{\text {excluded }}^{2}}{1-Q_{\text {included }}^{2}}
$$

Notes:

f2 : effect size

R2included : value R2 of endogen variable when a certain exogen variables is

put into the model

R2excluded : value R2 endogen variable when a certain exogen variables is taken out

from the model

q2 : effect size predictive relevance

Q2 : value of Q2 variable endogen when a certain exogen variable is put

into the model

Q2 : value of Q2 variable endogen when a certain exogen variable is taken out from the model

\section{E. Hypotheses Evaluation}

This evaluation is done by bootstrapping which could result in the relationship between exogen variable on endogen variable. This evaluation is also done by comparing the value of $t$ statistics with $t$ table. If the $t$ statistics is higher than t table (1.96), that signs that there is significant influence between a variable towards other variables. On the other hand, if it is lower than the number, then there is no significant influence.

\section{RESULTS AND DISCUSSION}

\section{A. Partial Least Square Analysis}

\section{Reliability and Validity Test}

Convergent Validity Test

Outer model evaluation using convergent validity of loading factor for each variables targeted by > 0.50. If the value is higher or is on the same value, it is considered an indicator, however, if it is not, it would not be considered as an indicator. 


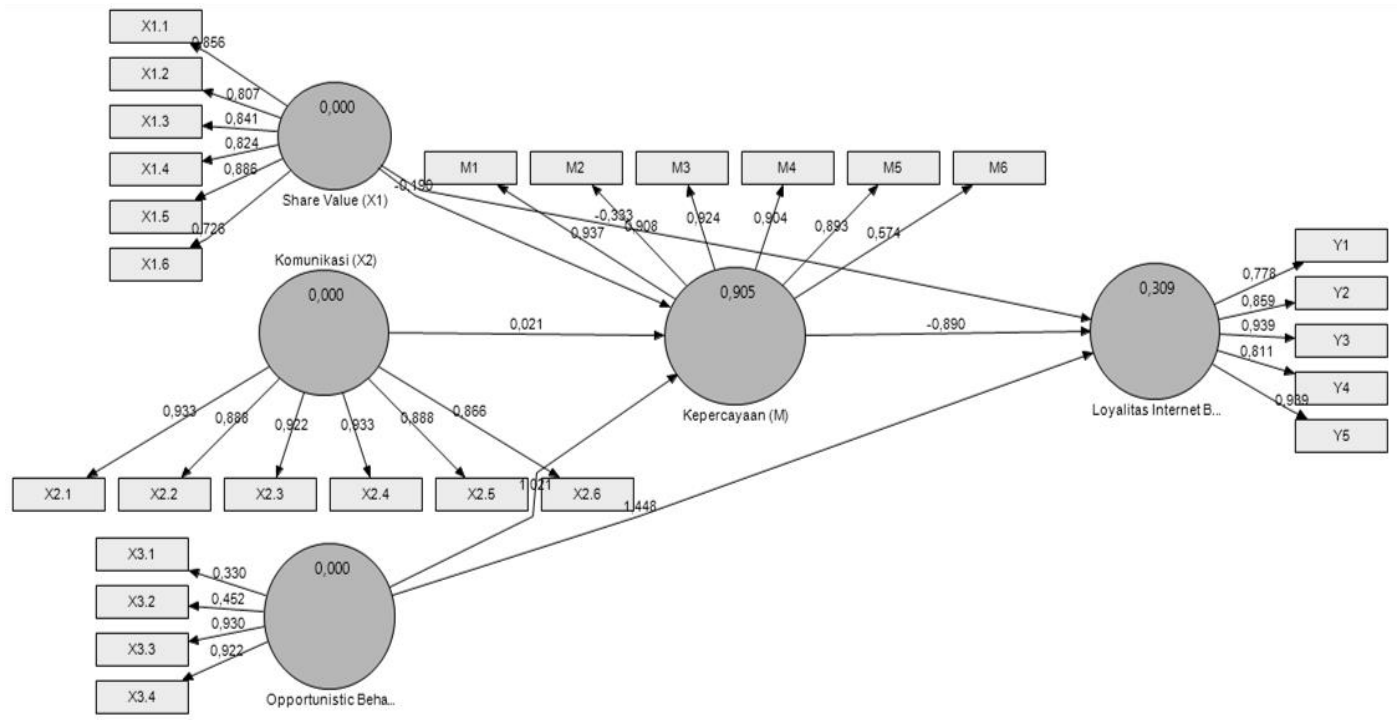

Figure 1 - Outer Model

According to the figure above, the variables has multiple indicators. These indicators are included if they fulfill the convergent validity of loading factor value of $>0.5$ for Share Value, Communication, Opportunistic Behavior Control, and Trust; and $>0.7$ for Loyalty. The indicators include:

(a) Share value $(\mathrm{X} 1)$ by 6 indicators $-\mathrm{X} 1.1=0.855 ; \mathrm{X} 1.2=0.806 ; \mathrm{X} 1.3=0.841 ; \mathrm{X} 1.4=0.824 ; \mathrm{X} 1.5=$ $0.886 ; \mathrm{X} 1.6=0.725$;

(b) Communication $(\mathrm{X} 2)$ by 6 indicators $-\mathrm{X} 2.1=0.933 ; \mathrm{X} 2.2=0.888 ; \mathrm{X} 2.3=0.922 ; \mathrm{X} 2.4=0.933$; $\mathrm{X} 2.5=0.888 ; \mathrm{X} 2.6=0.866$;

(c) Opportunistic Behavior Control (X3) by 4 indicators $-\mathrm{X} 3.1=0.330 ; \mathrm{X} 3.2=0.452 ; \mathrm{X} 3.3=0.930$; $\mathrm{X} 3.4=0.922$;

(d) Trust (M) by 5 indicators $-\mathrm{M} 1=0.936 ; \mathrm{M} 2=0.908 ; \mathrm{M} 3=0.924 ; \mathrm{M} 4=0.904 ; \mathrm{M} 5=0.893$;

(e) Loyalty $(\mathrm{Y})$ by 5 indicators $-\mathrm{Y} 1=0.778 ; \mathrm{Y} 2=0.859 ; \mathrm{Y} 3=0.939 ; \mathrm{Y} 4=0.810 ; \mathrm{Y} 5=0.939$.

Discriminant Vailidity

The next evaluation is by comparing between discriminant validity and square root of average variance extracted (AVE), the measurement model is valued basing on cross loading with constract. If the constract coleration with every indicator is higher than other constract, then the laten constract predicts the indicator is better than other constract. If the value is higher than the coleration value between constracts, then a better discriminant validity will be reached (if the AVE is $>0.7$ ).

Table 1. AVE value

\begin{tabular}{ll}
\hline & AVE \\
\hline Share Value (X1) & 0.700 \\
Communication (X2) & 0.819 \\
Opportunistic Behavior Control (X3) & 0.507 \\
Trust (M) & 0.750 \\
E-Banking Loyalty (Y) & 0.752 \\
\hline
\end{tabular}

Source: PLS

According to the measurements above, among 5 latent variables, there is one, the $\mathrm{X} 3$, that has two different indicators which is the X3.1 and X3.2. The value of X3 is lower than the others, which means it has to be re-evaluated - which leaves us with only the 4 remaining latent variables.

Composite Reliability Test

To decided on the composite reliability, the value $>0,8$ is considered high reliability and $>0,6$ is decent reliability. The result of reliability test could be seen below. 
Table 2. Composite reliability measurement

\begin{tabular}{ll}
\hline & Composite Reliability \\
\hline $\mathrm{X} 1$ & 0.927 \\
$\mathrm{X} 2$ & 0.964 \\
$\mathrm{X} 3$ & 0.941 \\
$\mathrm{M}$ & 0.946 \\
$\mathrm{Y}$ & 0.937 \\
\hline
\end{tabular}

Source : PLS

Cronbach Alpha Test

This test is to strengthen the reliability test in which consistency of every answer is tested. The condition for this test is it will be considered good if $\alpha \geq 0,6$ and it will be considered decent if $\alpha \geq 0,3$. Below is the Cronbach test results.

Table 3. Cronbach Alpha measurement

\begin{tabular}{ll}
\hline & Cronbachs Alpha \\
\hline X1 & 0.908023 \\
X2 & 0.960009 \\
X3 & 0.876345 \\
M & 0.927992 \\
Y & 0.916252 \\
\hline
\end{tabular}

Source : PLS

Inner Model

The value of R-square $>0$ shows model has predictive relevance, however, if it shows $\leq 0$ then it means that the model does not have enough predictive relevance. Below is th table for the inner model using PLS.

Table 4. R Square

\begin{tabular}{lll}
\hline & R Square & Adjusted R Square \\
\hline $\mathrm{Y}$ & 0.312 & 0.908 \\
\hline
\end{tabular}

Source : PLS

The R-square table above has reached 0.312 - explained by variable share value (X1), communication (X2), opportunistic behavior control (X3), and trust (M) that gives value 0.312 that could be interpreted that latent dependent variable is $31.2 \%$, while $90.8 \%$ is explained by variables outside the research's scope.

Bootstrapping 


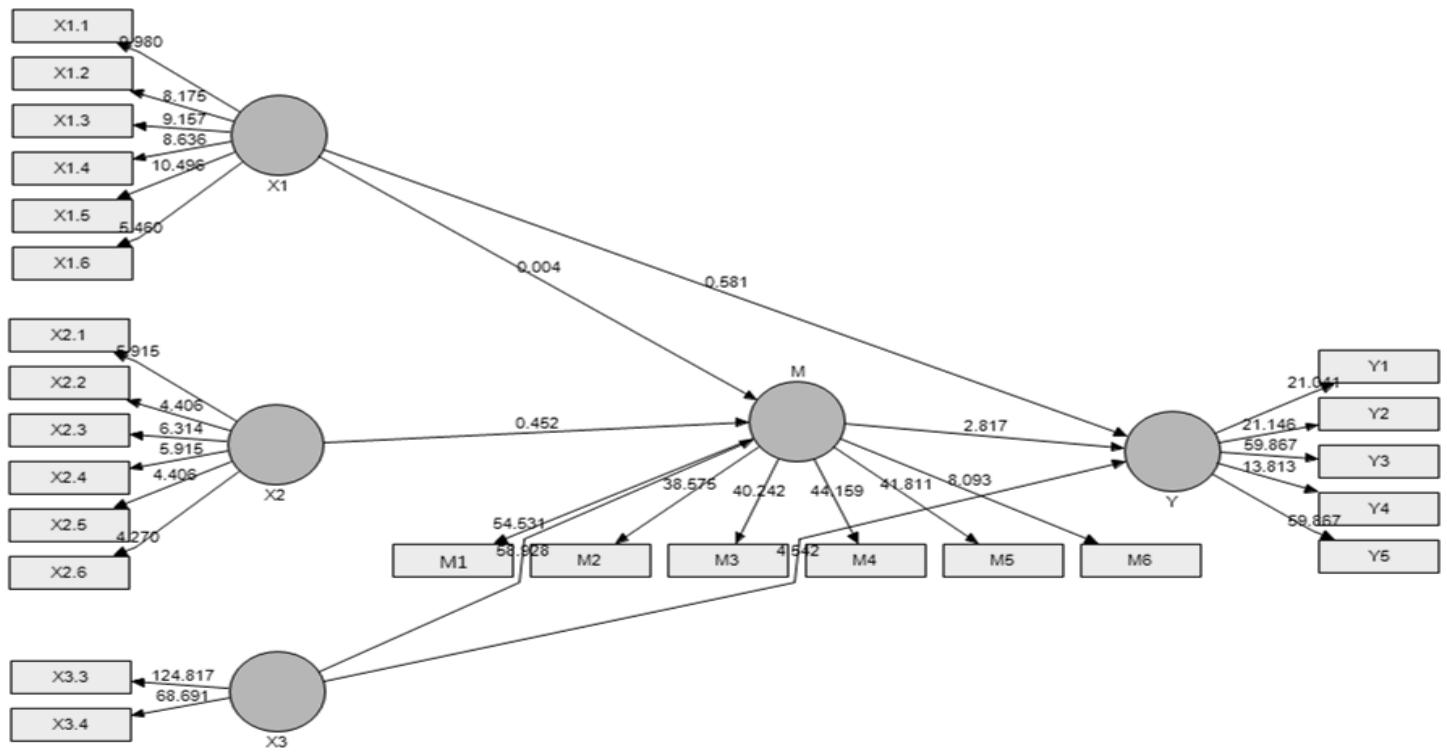

Figure 2. Bootstrapping PLS

\section{B. Hypotheses Testing}

The significance level $(\alpha)$ of $5 \%$ is included in the criteria for hypthosesis. The conditions are: (1) if the value of $t$ count $>t$ table (1.96), then the hypothesis will be accepted; and (2) if the value of $t$ count $<t$ table (1.96), the hypothesis will be rejected. See below for the tests.

Table 5. Bootstrapping Hypotheses $1-6 b$

\begin{tabular}{|c|c|c|c|c|c|c|}
\hline Hypotheses & Variables & $\begin{array}{l}\text { Original } \\
\text { Sample (O) }\end{array}$ & $\begin{array}{l}\text { Sample } \\
\text { Mean (M) }\end{array}$ & $\begin{array}{l}\begin{array}{l}\text { Standard } \\
\text { Deviation } \\
\text { (STDEV) }\end{array} \\
\end{array}$ & $\begin{array}{l}\text { Standard } \\
\text { Error } \\
\text { (STERR) }\end{array}$ & $\begin{array}{l}\text { Statistics } \\
\text { (|O/STERR } \mid)\end{array}$ \\
\hline H1 & $\mathrm{X} 1 \rightarrow \mathrm{M}$ & -0.190 & -0.189 & 0.090 & 0.090 & 2.587 \\
\hline $\mathrm{H} 2$ & $\mathrm{X} 2 \rightarrow \mathrm{M}$ & 0.021 & 0.019 & 0.041 & 0.041 & 0.524 \\
\hline $\mathrm{H} 3$ & $\mathrm{X} 3 \rightarrow \mathrm{M}$ & 1.021 & 1.033 & 0.049 & 0.049 & 20.776 \\
\hline $\mathrm{H} 4$ & $\mathrm{X} 1 \rightarrow \mathrm{Y}$ & $(0.333)$ & $(0.335)$ & 0.143 & 0.143 & 2.339 \\
\hline H5 & $\mathrm{X} 3 \rightarrow \mathrm{Y}$ & 1.448 & 1.423 & 0.357 & 0.357 & 4.052 \\
\hline H6 & $\mathrm{M} \rightarrow \mathrm{Y}$ & $(0.890)$ & $(0.844)$ & 0.344 & 0.344 & 2.587 \\
\hline H6a & $\mathrm{X} 1 * \mathrm{M} \rightarrow \mathrm{Y}$ & -0.622 & -0.956 & 0.695 & 0.695 & 0.895 \\
\hline $\mathrm{H} 6 \mathrm{~b}$ & $\mathrm{X} 3 * \mathrm{M} \rightarrow \mathrm{Y}$ & -1.147 & -1.220 & 0.503 & 0.503 & 2.280 \\
\hline
\end{tabular}

Source: PLS

1. The T-statistic of $\mathrm{H} 1, \mathrm{H} 3, \mathrm{H} 4, \mathrm{H} 5, \mathrm{H} 6$, and $\mathrm{H6}_{b}$, which is higher than the t-table (1.96), which means $\mathrm{H} 1$, $\mathrm{H} 3, \mathrm{H} 4, \mathrm{H} 5, \mathrm{H} 6$, and $\mathrm{H}_{\mathrm{b}}$ are accepted.

2. The T-statistic of $\mathrm{H} 2$ is only 0.524 , which is smaller than the $\mathrm{t}$-table (1.96). Therefore, $\mathrm{H} 2$ is rejected.

3. The T-statistics of $\mathrm{H}_{\mathrm{a}}$ is 0.895 which is smaller than the t-table. Ergo, $\mathrm{H}_{\mathrm{b}}$ is rejected.

\section{IV.CONCLUSION}

In conclusion, this study shows that:

1. Share value has positive influence on trust at Bank Jatim Surabaya.

2. Communication has negative influence on trust at Bank Jatim Surabaya.

3. Opportunistic Behavior Control has positive influence on trust at Bank Jatim Surabaya.

4. Share value has positive influence on customer's loyalty in using internet banking at Bank Jatim Surabaya. 
5. Opportunistic Behavior Control has positive influence on customer's loyalty in using internet banking at Bank Jatim Surabaya.

6. Trust has positive influence on customer's loyalty in using internet banking at Bank Jatim Surabaya.

7. Share value has negative influence towards customer's loyalty through trust in using internet banking at Bank Jatim Surabaya.

8. Opportunistic Behavior Control has positive influence towards customer's loyalty through trust in using internet banking at Bank Jatim Surabaya.

\section{ACKNOWLEDGEMENT}

This paper has no conflict of interest.

\section{REFERENCES}

Amin, M., Isa, Z., \& Fontaine, R. (2013). Islamic banks: Contrasting the drivers of customer satisfaction on image, trust, and loyalty of Muslim and non-Muslim customers in Malaysia. International Journal of Bank Marketing, 31(2), 79-97. https://doi.org/10.1108/02652321311298627

Barnes, J. G. (2013). Secerets of Customer Relationship Management. Jakarta: ANDI.

Chen, J., \& Dibb, S. (2010). Consumer trust in the online retail context: Exploring the antecedents and consequences. Psychology \& Marketing, 27(4), 323-346. https://doi.org/10.1002/mar.20334

Istiarni, P. R. D. I., \& Hadiprajitno, P. B. (2014). Analisis Pengaruh Persepsi Manfaat, Kemudahan Penggunaan Dan Kredibilitas Terhadap Minat Penggunaan Berulang Internet Banking Dengan Sikap Penggunaan Sebagai Variabel Intervening (Studi Empiris: Nasabah Layanan Internet Banking di Indonesia). Diponegoro Journal Of Accounting, 03(02), 1-10.

Kerlinger, F. N., \& Lee, H. B. (2000). Foundations of Behavioral Research. Australia: Wadsworth.

Kotler, P., \& K. (2016). Marketing Managemen. Jakarta: Erlangga.

Laroche, M., Habibi, M. R., \& Richard, M. O. (2013). To be or not to be in social media: How brand loyalty is affected by social media? International Journal of Information Management, 33(1), 76-82. https://doi.org/10.1016/j.ijinfomgt.2012.07.003

Nur, H., \& Jaka Isgiyarta, Y. (2015). Analisis Pengaruh Persepsi Nasabah Bank Terhadap Internet Banking Adoption (Studi Pada Nasabah Perbankan Yang Menggunakan Internet Banking Di Kota Surakarta). Diponegoro Journal Of Accounting, 4(1), 249118. Retrieved from http://ejournals1.undip.ac.id/index.php/accounting

Sa'diyah, M., \& Aziroh, N. (2014). Analisis Faktor-Faktor Yang Mempengaruhi Tingkat Kepercayaan Nasabah Muslim Pengguna Mobile Banking Di Bank Muamalat Indonesia 118 Kantor Cabang Pembantu Kudus. STAIN Kudus, l(1), 118-144. Retrieved from https://journal.iainkudus.ac.id/index.php/equilibrium/article/view/202

Taufan, M., Prakoso, R., \& Farida, N. (2018). Pengaruh Shared Value Dan Web Quality Terhadap Online Repurchase Intention Melalui Trust Sebagai Variabel Intervening (Studi Kasus Pada Mahasiswa Universitas Diponegoro Konsumen Lazada.Co.Id). Diponegoro Journal Of Social And Political, 7(3), 1-7. Retrieved from http://ejournal-s1.undip.ac.id/index.php/

Tumbel, A. (2017). Pengaruh Kepercayaan Dan Kepuasan Terhadap Loyalitas Nasabah Pada Pt Bank Btpn Mitra Usaha Rakyat Cabang Amurang Kabupaten Minahasa Selatan. Jurnal LPPM Bidang Ekososbudkum, 3(1), 64-79. $\quad$ Retrieved from https://ejournal.unsrat.ac.id/index.php/lppmekososbudkum/article/view/17186

wu, M., Weng, Y., \& Huang, I. (2012). A study of supply chain partnerships based on the commitment $\square$ trust theory. Asia Pacific Journal of Marketing and Logistics, 24(4), 690-707. https://doi.org/10.1108/13555851211259098 